\title{
How are young graduates settling into the labour market?
}

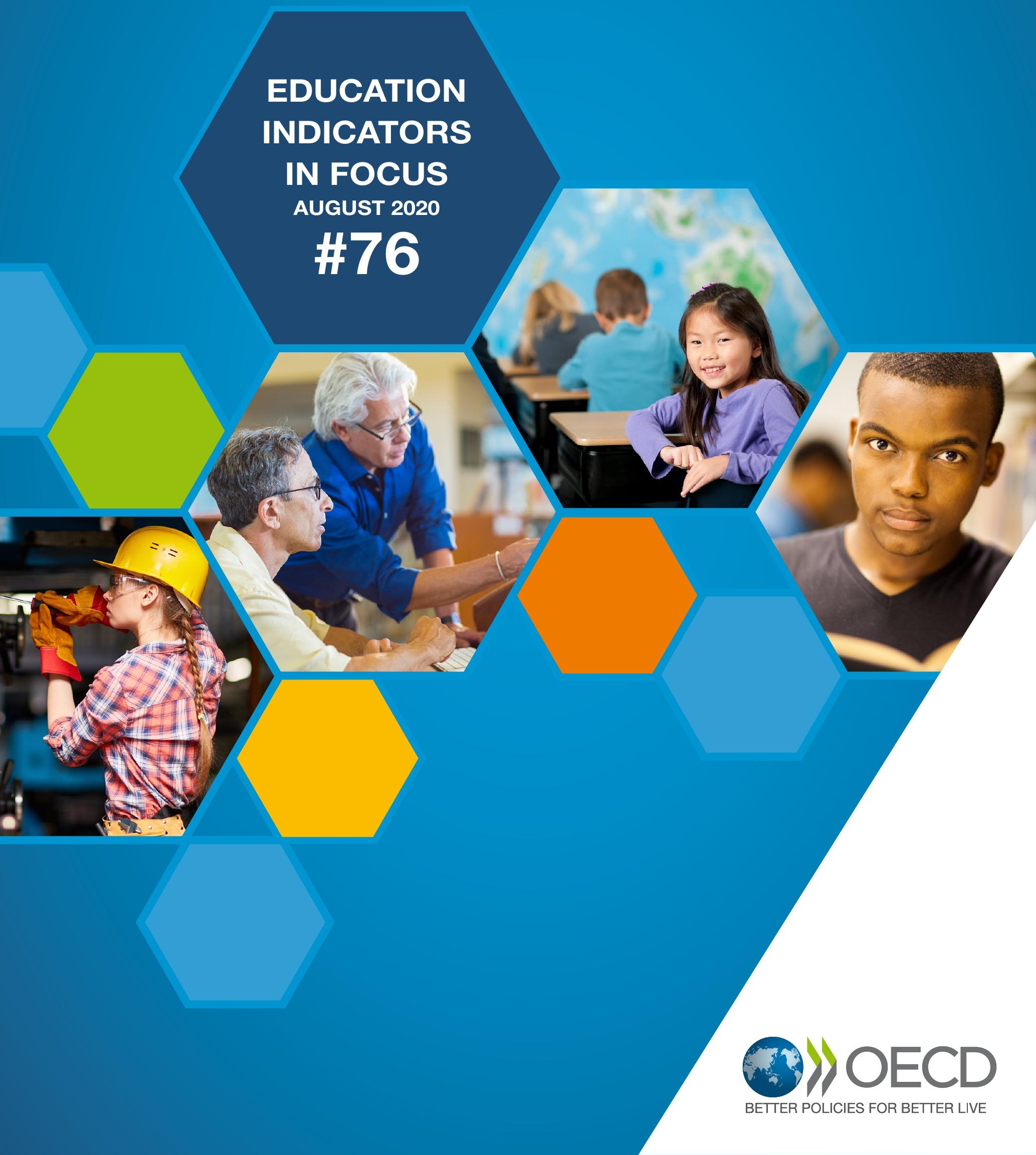


- On average across OECD countries and economies participating in the Survey of Adult Skills (PIAAC), 25-34 year-old tertiary graduates report having worked for 2.4 different employers in the past five years, compared to an average of 1.5 among 55-64 year-olds.

- Data from Linkedln profiles in eight OECD countries and economies show that bachelor's graduates hold an average of 2.6 different jobs or internships during the first five years after they complete their programmes. For master's graduates the average falls to 2.2 over the same period.

- Graduates who have worked in more than one industry are more likely to report some interpersonal skills on their Linkedln profile than their peers who have stayed in the same industry.

\section{Job changes among tertiary-educated adults by age group}

Each year, millions of graduates make the transition from tertiary education to work (OECD, 2019 ${ }_{[1]}$ ). A tertiary education puts them in a good position to start their journey into the world of work as it is associated with high levels of skills, employment and earnings across countries (OECD, 2019 ${ }_{[1]}$; OECD, $2019_{[2]}$; OECD, 2016 ${ }_{[3]}$ ). Moving between jobs and organisations is a common feature of this transitional period. Job mobility can increase wages and productivity by helping workers find a good match for their skills on the labour market (Neal, $2017_{[4]}$ ). However, the transition from tertiary education to work involves substantial uncertainty and can often be associated with stress, anxiety, fear, uncertainty and feelings of low self-worth (Perrone and Vickers, 2003 ${ }_{[5]}$ ). The labour-market conditions for younger adults are generally more precarious than for older and more experienced workers. The vulnerability of their position often results from temporary contracts, lower wages, unpaid overtime or undeclared work (OECD, 2019 [6]; OECD, 2018 $\left.{ }_{[7]}\right)$.

Economic uncertainty is likely to be exacerbated by the current crisis related to COVID-19, which is negatively affecting the employment prospects of new graduates and younger workers (OECD, 2020 $\left.{ }_{[8]}\right)$. The current crisis has left many firms without the resources to guarantee continued employment, with major repercussions for people in insecure employment. In addition, the COVID-19 crisis hit economic sectors asymmetrically, demanding a reallocation of labour and talents across them. These new developments make the transition between education and employment even more complex than in the past, increasing the importance of skills to adapt quickly to new and different jobs.

The OECD Programme for the International Assessment of Adult Competencies (the Survey of Adult Skills - PIAAC) asked adults, a few years before the COVID-19 crisis, how many different firms or organisations they have worked for in the past five years. The data show that the degree of job mobility is greater among 25-34 year-olds than among older age groups (which does not imply that mobility has increased over time). On average across OECD countries and economies, tertiary-educated 25-34 year-olds report having worked for 2.4 different firms or organisations in the past five years; this number goes down to 1.8 among 35-44 year-olds, 1.6 among 45-54 year-olds and 1.5 among 55-64 year-olds (Figure 1).

Job mobility varies significantly across countries. For example, in Japan, the Slovak Republic and Slovenia, the average number of different employers tertiary graduates have had in the past five years is under 1.8, regardless of their age group. In contrast, job mobility is high for all age groups in Chile, with adults reporting having worked for at least 2.3 different firms or organisations in the past five years. 
Figure 1. Number of firms or organisations tertiary-educated adults have worked for in the past five years, by age group $(2012,2015$ or 2017)

Survey of Adult Skills (PIAAC), tertiary-educated adults

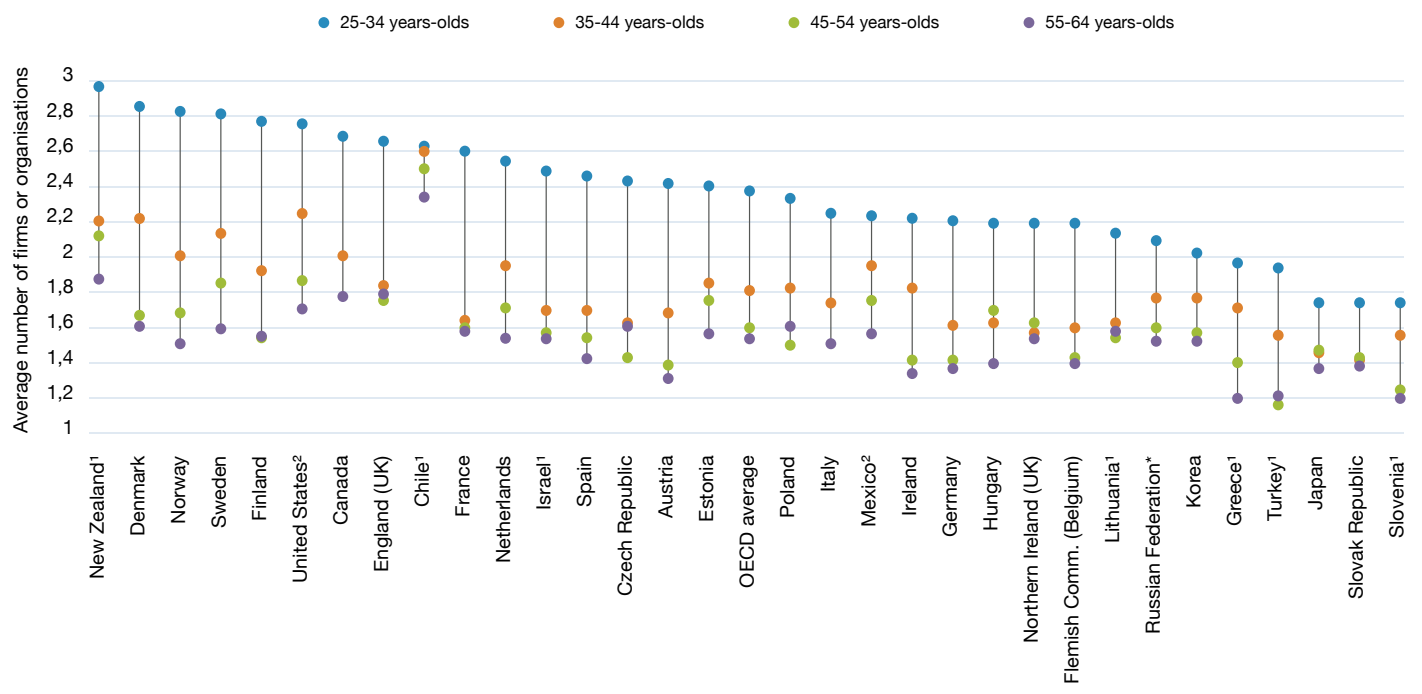

Note: Except where noted otherwise, the reference year is 2012

1. Reference year is 2015.

2. Reference year is 2017 .

* Regarding data from the Russian Federation in the Survey of Adult Skills (PIAAC): the sample for the Russian Federation does not include the population of the Moscow municipal area. The data published, therefore, do not represent the entire resident population aged 16-65 in the Russian Federation but rather the population of the Russian Federation excluding the population residing in the Moscow municipal area. More detailed information regarding the data from the Russian Federation as well as that of other countries can be found in the Technical Report of the Survey of Adult Skills, Second Edition (OECD, 2016 ${ }_{[9]}$ ). Source: Survey of Adult Skills (PIAAC).

\section{Graduates' transition to the labour market}

A more recent picture of the variety of professional experience graduates accumulate in the five years after completing tertiary education is offered by self-reported data collected through Linkedln, a platform for professional networking. Linkedln provided information on the self-reported number of jobs (used here to mean positions of all kinds internships as well as paid employment) held by members who graduated from a bachelor's or master's programme between 2010 and 2013 in eight countries and economies (Box 1).

\section{Box 1. Linkedln data}

The Linkedln data presented in this brief were provided by Linkedln on the OECD's request. The data cover around 7.8 million members living anywhere in the world who indicated that they earned their first bachelor's or master's degree between 2010 and 2013 in Australia, Canada, Estonia, the Flemish Community of Belgium, France, the Netherlands, Norway and the United States. To put this in context, the OECD estimate that there would have been around 14.5 million first-time bachelor's and master's graduates in those countries and economies over that period, based on data returned by jurisdictions included in the UNESCO-OECD-Eurostat (UOE) data collection. This analysis excludes Linkedln members who reported no experience (professional) in the five years after graduating (10\% of the total), as well as outliers who reported over seven different jobs ( $1 \%$ of the total). 
The Linkedln data analysed reflect the jobs - including both paid work and other professional experiences such as internships - listed under the heading "Experience" of the Linkedln profile (Figure 2) five years after the reported date of graduation. In other words, the data do not reflect employment status updates through time, but the information on the profile page at one point in time. The number of jobs adults report after graduating could be subject to bias. For example, graduates may remove jobs they value less in their profile to give more prominence to the jobs they value more.

Figure 2. Example of a Linkedin profile

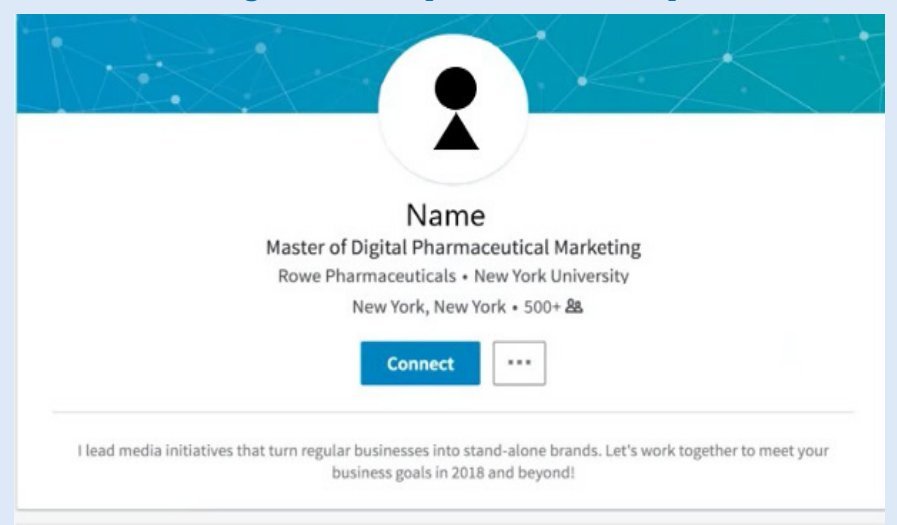

Experience

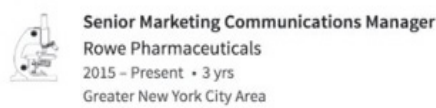

(a)

rebuilt Rowe's 12-person communications team to represent a range of marketing operations: event coordination, branding, public relations, and business development. In 2017, our team

Media (1)

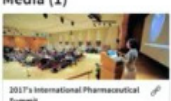

Marketing Communications Manager

Enzyme Labs

$2011-2015 \cdot 4$ yrs

Jersey City, NJ

I was initially hired as the third member of a new marketing team to support Enzyme's growth

from a start-up organization. After one year, I was promoted from Communications Associate

Communications Manager, and helped spearhead branding for employees, customers, an

Education

- New York University

Bachelor's degree, Business Marketing

NYU

Featured Skills

Project Managem...

ROI

Branding
Interests

1. New York University

496,167 followers

. Rowe Pharmaceuticals

The level of education of Linkedln members has been derived from Linkedln's own recording, and may not coincide exactly with the bachelor's and master's or equivalent levels as defined in by the International Standard Classification of Education (ISCED). 
Figure 3 shows that first-time bachelor's graduates in the eight countries and economies with data report holding 2.6 different jobs (including internships) on average in the five years after completing their degrees. The number ranges from 2.3 in Estonia and Norway to 2.9 in the Netherlands and 3.2 in France. These results suggest varying degrees of job stability across countries, which are not necessarily related to the situation in the labour market. When employment rates are high, graduates are in high demand and may choose to change jobs frequently if better conditions are offered. In contrast, when employment rates are low, graduates may only have precarious contracts and therefore be more likely to change jobs on an involuntary basis. The result is the same in both cases, but the underlying causes are different. For example, graduates in the Netherlands and France have held a similar number of jobs during the five years after graduation, even though the employment rate of 25-34 year-olds with a bachelor's or a master's degree is much lower in France. In all cases, however, the frequency of job changes is likely to be affected by the current COVID-19 crisis, which is affecting labour demand differently across different industries and may require a reallocation of labour resources across sectors.

Figure 3. Employment rate (2018) and labour-market experiences of bachelor's and master's graduates (2015-18)

Employment rate of 25-34 year-old graduates and the average number of different jobs and internships in the five years after graduation among Linkedln members reporting earning their first degree between 2010 and 2013, by level of education
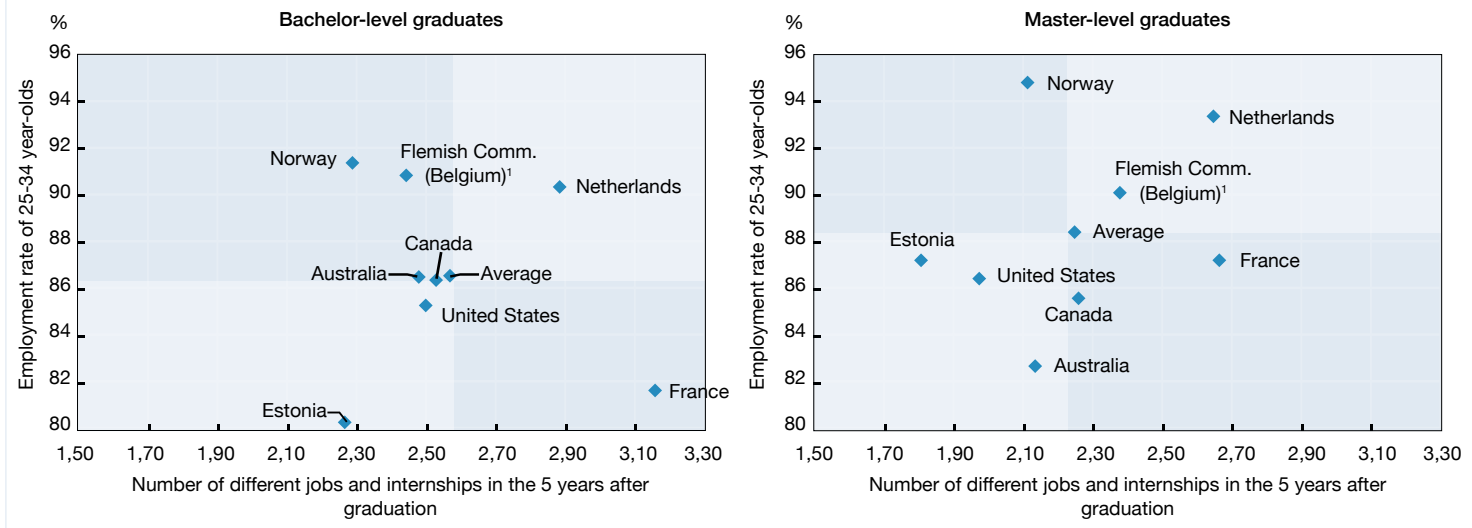

1. Year of reference for the employment rate is 2017

Source: Education at a Glance 2019 and Linkedln aggregate data provided at the OECD's request.

First-time graduates from master's programmes report holding 2.2 positions over the same time frame (Figure 3) on average across countries and economies with data. This is fewer than for bachelor's graduates, but it still means that many of them have had to adapt to a number of different work environments in the years following graduation. Just $25 \%$ of master's graduates reported having held only one job in the five years after their graduation (source: background data provided by Linkedln), meaning that for the majority, the job they find after their studies will not be one they keep for a long period.

Job changes can be voluntary or involuntary, making it difficult to assess if they are good or bad outcomes in themselves. However, they raise important questions for policy makers and tertiary education institutions, especially in light of the major disruption of the labour market that the COVID-19 crisis is bringing about. Many graduates will need to change jobs, and they must be prepared for that. What type of transferable skills do graduates need to withstand dynamic labour-market transitions? How can they be prepared for jobs that could frequently change?

\section{Dynamic transitions and interpersonal skills}

Dynamic labour markets require a diverse set of skills, including technical skills, creative thinking, and social and behavioural skills. Many higher education institutions have introduced teaching methods (e.g. problem- and projectbased learning) with the purpose of developing such a diverse set of skills (Hoidn and Kärkkäinen, 2014 ${ }_{[10]}$ ). The data from Linkedln also suggest that graduates moving between industries find interpersonal skills valuable to include in their professional profile (Figure 4). Indeed, those seeking to change industry often highlight transferable skills on their profile as they cannot highlight expertise in the targeted industry. 
Figure 4. Percentage of bachelor's and master's graduates reporting at least one interpersonal skill on their LinkedIn profile, by labour-market trajectory (2015-18)

Linkedln members reporting to have earned their first bachelor's or master's degree between 2010 and 2013, who during the five years following their graduation had:

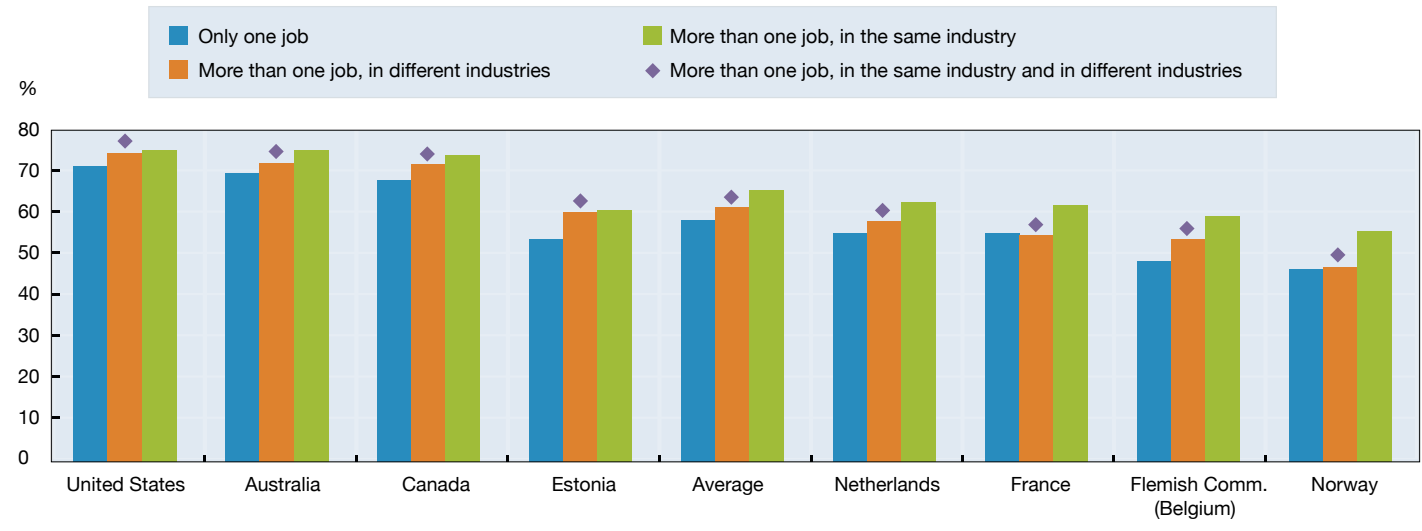

Note: Graduates without work experience are excluded from the chart. The level of education has been derived from Linkedln's own recording, and may not coincide exactly with bachelor's or master's level as defined in the ISCED classification. The statistical significance of the results is not reported as the results refer to the whole population of Linkedln members.

Source: Linkedln aggregate data provided at the OECD's request.

Figure 4 shows the proportion of first-time graduates reporting at least one interpersonal skill on their Linkedln profile. In all eight of the countries and economies with data available, interpersonal skills appear more often in the profiles of graduates with more dynamic career trajectories. On average, $57 \%$ of graduates who had only one job (whether paid employment or an internship) in the five years after graduation included at least one interpersonal skill in their profile, increasing to $60 \%$ among those who changed jobs but not industry, and reaching $64 \%$ for those who changed industries as well.

Graduates who report more than one job in different industries and those who report more than one job in the same industry are the two most closely comparable groups, for example in terms of the total number of reported skills and work experiences. In the Flemish Community of Belgium, France, the Netherlands and Norway, members who have worked in different industries are at least 5 percentage points more likely to report at least one interpersonal skill than those who changed job but stayed in the same industry. In Estonia and the United States, the difference is 1 percentage point (Figure 4).

The interpersonal skills included in Figure 4 are drawn from a list of keywords for intrapersonal, interpersonal, management and problem-solving skills provided by Binkley et al. $\left(2005_{[11}\right)$. They include communication, leadership, teamwork, time management, contract negotiation and many others. Table 1 lists the two interpersonal skills most frequently reported by graduates in each of the eight education systems analysed. 
Table 1. Most common and second most common interpersonal skills (2018))

As reported by Linkedln members reporting to have earned their first bachelor's or master's degree between 2010 and 2013

\begin{tabular}{lrr} 
& Most common & Second most common \\
\hline Australia & Leadership & Communication \\
Canada & Leadership & Communication \\
Estonia & Communication & Teamwork \\
Flemish Community & Teamwork & Communication \\
France & Communication & Training \\
Netherlands & Teamwork & Communication \\
Norway & Teamwork & Leadership \\
United States & Leadership & Public speaking
\end{tabular}

Note: Skills reported in languages other than English have been translated into English to perform the calculations. Source: Linkedln aggregate data provided at the OECD's request.

There are at least two possible explanations why graduates who changed industry for work are reporting more interpersonal skills on Linkedln than other graduates. It could be that graduates with more interpersonal skills are more likely to transition between industries because they can adapt better to different environments. However, it could also be that graduates who are looking for jobs outside their current industry report additional interpersonal skills as a way to portray themselves as flexible employees, even if they do not have these skills. In either case, these results suggest that graduates, especially those with more dynamic early careers, find interpersonal skills valuable in their professional profile.

\section{The bottom line}

The transition from tertiary education to work involves substantial uncertainty and changes between education programmes, jobs and industries. The current major disruption in the labour market is only going to increase this uncertainty, making it essential for graduates to be prepared for it. Graduates with more dynamic career trajectories are more likely to include interpersonal skills in their professional profiles. This confirms the need for higher education institutions to pursue their efforts to develop a comprehensive skill set for their graduates, including technical skills and also interpersonal skills. 


\section{REFERENCES :}

[11] Binkley, M. et al. (2005), "Moving towards measurement: The overarching conceptual framework for the ALL Study", in Murray, T., Y. Clermont and M. Binkley (eds.), Measuring Adult Literacy and Life Skills: New Frameworks for Assessment, Statistics Canada, Ottawa.

[10] Hoidn, S. and K. Kärkkäinen (2014), "Promoting skills for innovation in higher education: A literature review on the effectiveness of problem-based learning and of teaching behaviours", OECD Education Working Papers, No. 100, OECD Publishing, Paris, https://doi.org/10.1787/5k3tsj67l226-en.

[4] Neal, D. (2017), "Life cycle wage dyamics and labor mobility", Journal of Political Economy, Vol. 125/6, pp. 1853-1862, http://dx.doi.org/10.1086/694690.

[3] OECD (2016), Skills Matter: Further Results from the Survey of Adult Skills, OECD Skills Studies, OECD Publishing, Paris, https://dx.doi.org/10.1787/9789264258051-en.

[9] OECD (2016), Technical Report of the Survey of Adult Skills (PIAAC), 2nd Edition, OECD, Paris, http://www.oecd.org/skills/piaac/PIAAC Technical Report 2nd Edition Full Report.pdf.

[7] OECD (2018), Education at a Glance 2018: OECD Indicators, OECD Publishing, Paris, https://dx.doi.org/10.1787/eag-2018-en.

[2] OECD (2019), Benchmarking Higher Education System Performance, Higher Education, OECD Publishing, Paris, https://dx.doi.org/10.1787/be5514d7-en.

[1] OECD (2019), Education at a Glance 2019: OECD Indicators, OECD Publishing, Paris, https://doi.org/10.1787/f8d7880d-en.

[6] OECD (2019), OECD Employment Outlook 2019: The Future of Work, OECD Publishing, Paris, https://dx.doi.org/10.1787/9ee00155-en.

[8] OECD (2020), OECD Employment Outlook2020: Worker Security and the COVID-19 Crisis, OECD Publishing, Paris, https://dx.doi.org/10.1787/1686c758-en.

[5] Perrone, L. and M. Vickers(2003), “Lifeaftergraduationasa ‘very uncomfortableworld': AnAustralian case study", Education + Training, Vol. 45/2, pp. 69-78, http://dx.doi.org/10.1108/00400910310464044.

\section{CONTACTS:}

Gabriele Marconi (Gabriele.MARCONI@oecd.org) and Simon Normandeau (Simon.NORMANDEAU@oecd.org)

Photo credit: () Christopher Futcher / iStock; @ Marc Romanelli / Gettyimages; @ michaeljung / Shutterstock; @ Pressmaster / Shutterstock

This work is published under the responsibility of the Secretary-General of the OECD. The opinions expressed and arguments employed herein do not necessarily reflect the official views of OECD member countries.

This document, as well as any data and any map included herein, are without prejudice to the status of or sovereignty over any territory, to the delimitation of international frontiers and boundaries and to the name of any territory, city or area.

The statistical data for Israel are supplied by and are under the responsibility of the relevant Israeli authorities. The use of such data by the OECD is without prejudice to the status of the Golan Heights, East Jerusalem and Israeli settlements in the West Bank under the terms of international law. 